\title{
Type of Remedial Action ICSR Terminology
}

National Cancer Institute

\section{Source}

National Cancer Institute. Type of Remedial Action ICSR Terminology. NCI Thesaurus. Code C54594.

Terminology used in Individual Case Safety Reports to specify a type of remedial action after an adverse event occurs, section H7 of FDA MedWatch Form. 